\title{
200 Year interruption of Holocene sapropel formation in the Adriatic Sea
}

\author{
E. J. ROHLING, ${ }^{1}$ F. J. JORISSEN ${ }^{2} \&$ H. C. DE STIGTER ${ }^{3}$ \\ ${ }^{1}$ Department of Oceanography, University of Southampton, Southampton, Hampshire SO14 3ZH, UK. \\ ${ }^{2}$ Département de Géologie et Océanographie, CNRS URA 197, Université de Bordeaux I, Avenue des Facultés, 33405 Talence \\ Cedex, France. \\ ${ }^{3}$ Department of Geology, Utrecht University, Institute of Earth Science, PO Box 80.021 , Utrecht, The Netherlands.
}

\begin{abstract}
An interruption of Holocene sapropel $S_{1}$ is found in cores from various subbasins of the eastern Mediterranean. In core IN68-9 from the Adriatic Sea, sapropel $S_{1}$ is dated between 8300 and 6340 $\mathrm{BP}$, interrupted between 7100 and $6900 \mathrm{BP}\left({ }^{14} \mathrm{C}\right.$ years uncorrected for reservoir age). Lithology and variations in the foraminiferal faunas suggest that the interruption is genuine, and not the result of resedimentation. The results indicate that $S_{1}$ was deposited within a period of enhanced levels of productivity (resulting from increased seasonal contrasts) which started around $9300 \mathrm{BP}$ and ended around 5200 BP. The onset, interruption, and final ending of $S_{1}$ deposition in the Adriatic Sea, however, appear to have been triggered by changes in ventilation of the basin related to changes in sea surface temperature (SST). Although the rough estimates of SST change are relatively small $\left(<2^{\circ} \mathrm{C}\right)$, they still are significant when compared with the relative SST changes considered necessary to upset convection in the Adriatic. Moreover, recent studies show that the influence of the inferred temperature changes should be viewed in combination with that of reduced salinities due to (1) the deglaciation, and (2) increased humidity in the eastern Mediterranean area during the deposition of $S_{1}$. The lithological and benthic foraminiferal evidence that sapropel formation in the Adriatic Sea ended around $6340 \mathrm{BP}$ contrasts with the conclusion from a recent geochemical study that sapropel formation in the open eastern Mediterranean would have ended as late as 5000 BP. More significantly, the results of the present study combined with other reports on sapropel interruptions suggest that the process of sapropel formation is not a very stable mode in the basin, but that it may be relatively easily interrupted in response to subtle rearrangements in the balance between productivity and, especially, deep water ventilation. J. Micropalaeontol. 16(2): 97-108, October 1997
\end{abstract}

\section{INTRODUCTION}

In the eastern Mediterranean, organic carbon rich, often laminated, intervals (sapropels) have been deposited since at least early Pliocene times (Cita \& Grignani, 1982; Thunell et al., 1984; Hilgen, 1991). Sapropel formation has been shown to be astronomically timed, occurring around minima in the precession cycle (Rossignol-Strick, 1985; Hilgen, 1991). The most recent sapropel, $S_{1}$, was deposited in the early Holocene. AMS ${ }^{14} \mathrm{C}$ dates for $\mathrm{S}_{1}$ range from: 8700-6000 BP (Troelstra et al., 1991; Lander Rasmussen, 1991); 8300-6340 BP (Jorissen et al., 1993) and 9200-6400 BP (Perissoratis \& Piper, 1992), which agree with earlier ${ }^{14} \mathrm{C}$ based estimates (Stanley \& Maldonado, 1979; Vergnaud-Grazzini, 1985). Higgs et al. (1994) proposed that the formation of $S_{1}$ ended much later, around $5000 \mathrm{BP}$, and that postdepositional downward oxidation of the sapropel created an apparent sapropel-top with an older age than the original top. They suggested that the original top resided close to the level of their upper Mn peak (about $5000 \mathrm{BP}$ ), but also that this should be verified with benthic foraminiferal faunas.

A pale-coloured horizon interrupts the dark-coloured appearance of $S_{1}$ in several cases from various subbasins of the central and eastern Mediterranean (Table 1). Sapropels $S_{6}$ and $S_{8}$ are also composite (e.g. Cita et al., 1977; Vergnaud-Grazzini et al., 1977; Blechschmidt et al., 1982; Cita \& Grignani, 1982; Cita et al., 1984; Vergnaud-Grazzini, 1985). Since these older sapropels are only encountered in long cores, usually from areas with low sedimentation rates, it is hard to study them in sufficient detail to pay special attention to the interruptions. High sedimentation rate cores allow greater resolution, which should enable us to discern whether the interruptions are a sedimentological feature,

\begin{tabular}{lll}
\hline Location & \multicolumn{1}{c}{$\begin{array}{c}\text { Depth range } \\
(\mathrm{m})\end{array}$} & Sources \\
\hline & & $1-6$ \\
Adriatic Sea & $700-1250$ & 7 \\
$\begin{array}{l}\text { Northern Aegean Sea } \\
\text { Core T171-24 NE off Lybia }\end{array}$ & $260-425$ & 8 \\
$\begin{array}{l}\text { Cores T36 and M18, } \\
\text { western Hellenic Trench }\end{array}$ & 2380 & 9 \\
$\begin{array}{l}\text { Core Medor 75 KS52, northern } \\
\text { Levantine Basin, Strabo Trench, SE } \\
\text { of Crete }\end{array}$ & 3118 & 10 \\
$\begin{array}{l}\text { Core PC10, central Herodotus } \\
\text { Abyssal Plain, off NW Egypt }\end{array}$ & 3198 & 11 \\
$\begin{array}{l}\text { Core 10, Cobblestone Area 4 } \\
\text { Mediterranean Ridge, N. Ionian }\end{array}$ & 3832 & 12 \\
Basin & & \\
\hline
\end{tabular}

Table 1. Reported occurrence of interruption within Holocene sapropel $S_{1}$. Sources: 1, Bottema \& Van Straaten (1966); 2, Van Straaten (1966); 3, Van Straaten (1970); 4, Van Straaten (1972); 5, Van Straaten (1985); 6, Jorissen et al. (1993); 7, Perissoratis \& Piper (1992); 8, Thunell et al. (1977); 9, Stanley et al. (1978); 10, Rossignol-Strick et al. (1982); 11, Cita et al. (1984); 12, Vismara-Schilling (1984).

as suggested by Stanley et al. (1978), or a genuine interruption of the process of sapropel formation.

Although several such cores containing $S_{1}$ have been discussed, almost none of the studies discussed its two-layered appearance. The thin homogenized interruption interval within $S_{1}$ is only obvious (and can only be sampled for faunal analysis) in cores from exceptional settings with high sedimentation rates, 


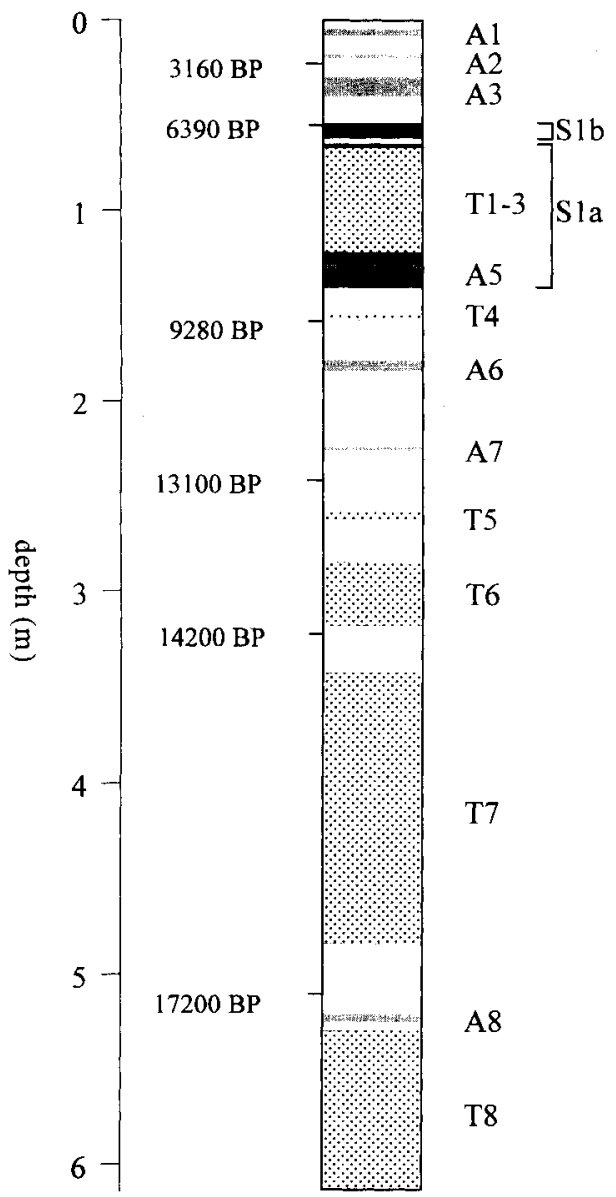

Fig. 1. Lithology of core IN68-9. Ages displayed to the left of the core are $\mathrm{AMS}^{14} \mathrm{C}$ datings (after Jorissen et al., 1993). To the right of the core, $A$ indicates ash-layer and $T$ turbidites. Interpolated ages of the various horizons, including the two $S_{1}$ subunits, are given in Table 2 . The original lithological description was made by Van Straaten (1970; also unpubl. data).

such as the Adriatic Sea. Within this context, we focus on the nature of the $S_{1}$ interruption in piston-core IN68-9 from the southern Adriatic Basin (Fig. 1), where $S_{1}$ was found to be distinctly two-layered at most sites deeper than $800 \mathrm{~m}$ (Table 1). The inferred implications for productivity and deep water ventilation in the Adriatic Sea may well be relevant to the entire eastern Mediterranean, since the Adriatic Sea plays a crucial role in the oxygenation of bottom waters in that basin (Pollak, 1951; Wüst, 1961; Mangini \& Schlosser, 1986; Malanotte-Rizzoli \& Hecht, 1988).

First, a time-stratigraphic framework is constructed for the core, on the basis of $\mathrm{AMS}^{14} \mathrm{C}$ dating results (Jorissen et al., 1993), verified with an oxygen isotope record (Figs $2 \& 3$ ). Then, the overall changes in the planktic and benthic foraminiferal faunas (Figs $3 \& 4$ ) are integrated with lithological variations in the upper $310 \mathrm{~cm}$ of IN68-9 (about 14000 to $3000 \mathrm{BP}$ ). This is followed by a synthesis of key indicator species for (1) sea surface temperature (SST), (2) productivity of the benthic ecosystem, and (3) sea floor oxygenation (Figs 3, 4 \& 5), on the basis of which the processes are reconstructed that caused the onset, interruption and ending of $S_{1}$ formation.

\section{CORE IN68-9}

\section{General description}

Core IN68-9 from the southern Adriatic Sea $\left(41^{\circ} 47^{\prime} 5 \mathrm{~N}, 17^{\circ} 54^{\prime} 5\right.$

$\mathrm{E} ; 1234 \mathrm{~m}$ water-depth) is used as the standard core in a recently proposed biochronology for the central Mediterranean, its chronology being constrained by $6 \mathrm{AMS}^{14} \mathrm{C}$ datings (Jorissen et al., 1993). Previous studies on IN68-9 concerned benthic and pelagic molluscs (Van Straaten, 1970: his core 362A) and - on a much coarser scale - planktic and benthic foraminifera for biostratigraphic and longer-term palaeoceanographic purposes (Jorissen et al., 1993; Rohling et al., 1993a).

For the present study, we strongly increased the detail of the foraminiferal records in the late glacial to Holocene interval $\left(310-0 \mathrm{~cm}\right.$ ) (Figs 3, $4 \& 5$ ). The record through sapropel $S_{1}$ now averages about one sample per 100-200 years (Table 2). IN68-9 mainly consists of hemipelagic muds, including a dark-coloured laminated sapropel, alternating with several ash-layers and turbidites (Fig. 1). The hemipelagic muds typically contain about $0.5 \%$ organic carbon, while values in the sapropel fluctuate between 0.9 and $2.1 \%$ (Fig. 5). Sapropel $S_{1}$ is found between 140 and $54 \mathrm{~cm}$. Within $S_{1}$, an ash-layer is present between 130 and $128 \mathrm{~cm}$, and a turbiditic interval between 122 and $67 \mathrm{~cm}$. In addition, the sapropel was found to be interrupted by a distinct, lighter coloured and apparently homogeneous interval between 65 and $62 \mathrm{~cm}$. Two samples were taken from this narrow interval, while immediately past its base and top a sample was taken from the adjacent sapropelic sediments (Table 2). Carbonate preservation was observed to be excellent throughout the core, as witnessed also by the continuous presence of aragonitic pteropod shells.

\section{Age model}

Accelerator mass spectrometer ${ }^{14} \mathrm{C}$ results. Table 2 lists the $\mathrm{AMS}^{14} \mathrm{C}$ dating results (see Jorissen et al., 1993) and interpolated ages for the various stratigraphic horizons and investigated samples in core IN68-9. After correction of the uncorrected $\left({ }^{14} \mathrm{C}_{\mathrm{nc}}\right)$ ages for a reservoir age of about 400 years, giving corrected $\left({ }^{14} \mathrm{C}_{\mathrm{c}}\right)$ ages, the datings could be converted to calendar years (Stuiver et al., 1991; Stuiver \& Reimer, 1993). Since the present study concentrates on the formation of $S_{1}$ and processes shortly before and after that, and since sample resolution is not much finer than 1 sample per century, the relatively minor Holocene ${ }^{14} \mathrm{C}$-platforms do not appreciably affect the results. The main platforms influencing ${ }^{14} \mathrm{C}_{\mathrm{c}}$ dates occur earlier, around 9600 (calendar-age range 10400 $10800 \mathrm{BP}$ ) and $10000 \mathrm{BP}$ (calendar-age range 11000 $11200 \mathrm{BP}$ ) (Stuiver et al., 1991), intervals we do not particularly concentrate on and where, consequently, sample resolution is much lower anyway ( 1 per 200 to 300 years; Table 2). Figure 2 shows the age versus depth plots for core IN68-9, in two forms: (1) with turbidites and ash-layers included, assuming quasiinstantaneous deposition for those intervals (cf. Jorissen et al., 1993), and (2) excluding the turbidites and ash-layers. Especially the plot versus calendar years shows an almost straight line since about $15000 \mathrm{BP}$, suggesting absence of any major non-linearity 


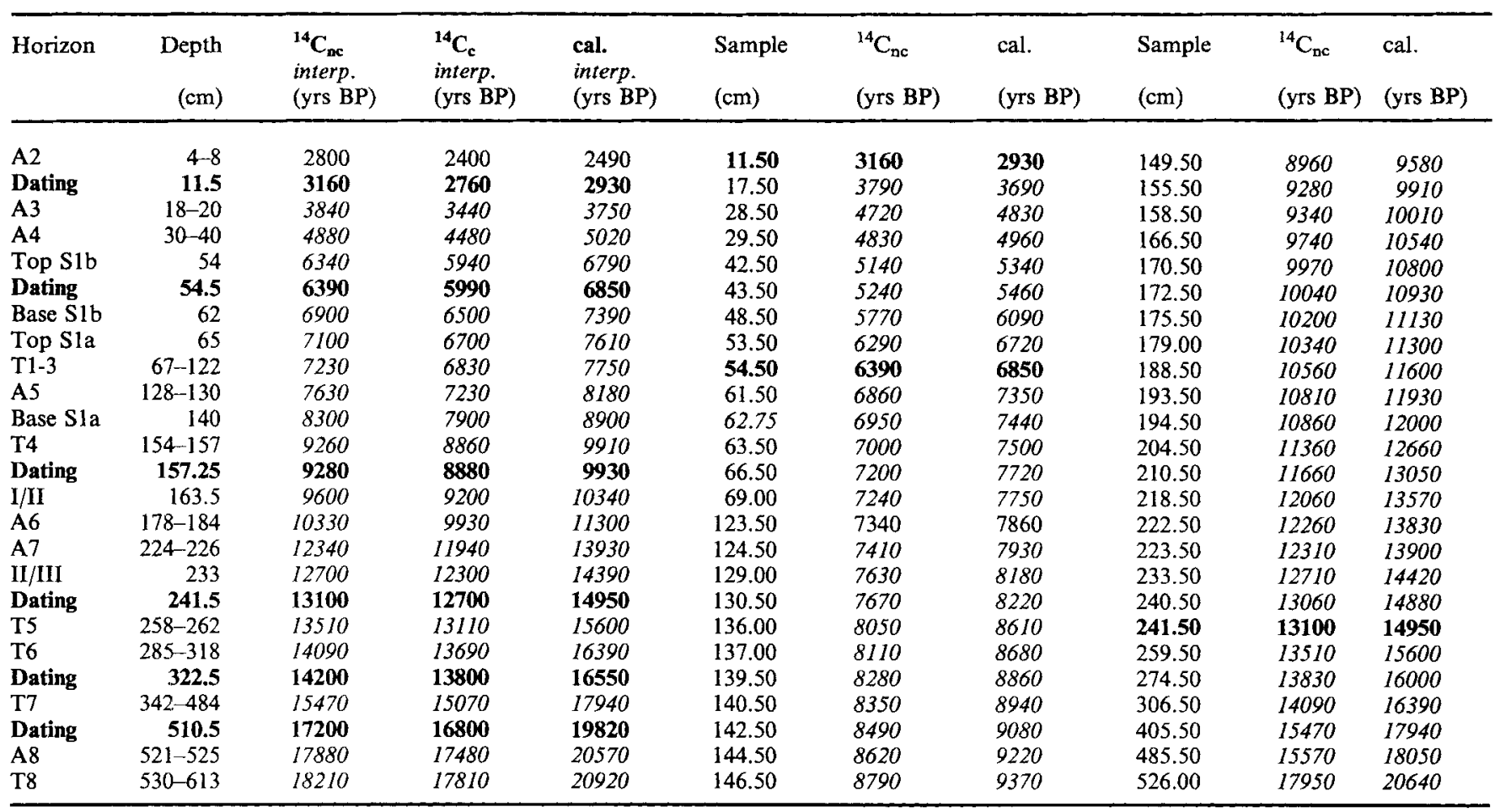

Table 2. Left-hand side: Stratigraphic horizons in core IN68-9. A = Ash; T=Turbidite; II/III and I/II = Faunal Zones II/III and I/II boundaries (Jorissen et al., 1993). Bold: AMS ${ }^{14} \mathrm{C}$ dated levels (Jorissen et al., 1993). Italics: inter-/extrapolated from dated levels. Inter/extrapolation was performed separately for radiocarbon and calendar year columns, as the relation between the two is non-linear. ${ }^{14} \mathrm{C}_{\mathrm{nc}}=\mathrm{ages}_{\mathrm{n} c o r r e c t e d}$ for reservoir age, ${ }^{14} \mathrm{C}_{\mathrm{c}}=$ corrected for reservoir age of 400 years (Bard, 1988; Broecker et al., 1988b; Bard et al., 1990). Cal. = calendar years BP, according to Stuiver \& Reimer (1993) and Stuiver et al. (1991), calculated with programme Calib3.0, using dataset-3 and $\Delta \mathrm{R}=0$. Right hand side: Investigated samples, ${ }^{14} \mathrm{C}_{\mathrm{nc}}$ ages and calendar ages. Bold = samples corresponding to $\mathrm{AMS}^{14} \mathrm{C}$ dated levels. Italics = inter-/extrapolated ages. Inter/extrapolation again performed separately for radiocarbon and calendar year columns.

that might upset the (interpolated) time-relations inferred in this paper (cf. Table 2).

Since the offsets between the time-scales of changes expressed in ${ }^{14} \mathrm{C}$ and calendar-ages (Table 2, Fig. 2) are relatively minor in the early Holocene interval that we concentrate on, we opt for using the primary dating results. We plot and discuss our results in terms of uncorrected ${ }^{14} \mathrm{C}$ years $\left({ }^{14} \mathrm{C}_{\mathrm{nc}}\right)$, instead of correcting them for reservoir age in the Mediterranean, since this reservoir age might be subject to future adjustments from the approximated 400 years.

Stable oxygen isotope results. To verify the time-stratigraphic framework based on the radiocarbon datings, a $\delta^{18} \mathrm{O}$ record has been constructed. This had to be been done using the planktic foraminiferal species Globigerina bulloides (Fig. 3), instead of the more commonly used Globigerinoides ruber, because only $G$. bulloides was found in sufficient numbers throughout the core. Unlike $G$. ruber, $G$. bulloides is not a shallow dwelling summer mixed-layer species. Today, it thrives in the western Mediterranean in winter and/or (late) spring (Vergnaud-Grazzini, 1973; Cifelli, 1974; Devaux, 1985; Vergnaud-Grazzini et al., 1986). Therefore, and since the analysing equipment required $>40$ specimens per sample, the $\delta^{18} \mathrm{O}_{\text {bulloides }}$ measurements are crude 'averages' only, influenced by lateral/vertical advection in the water column and by the combination of specimens from various seasons and various years within one measurement. Polynomial smoothing is applied to the record to highlight the major trends, which we do consider to be relatively robust and reliable (Fig. 3).

The smoothed $\delta^{18} \mathrm{O}$ record (Fig. 3) shows a basically two-step deglaciation, even if no marked (Younger Dryas) return to glacial conditions is found in between. The first step, at the base of the studied section of IN68-9, ends around $12700 \mathrm{BP}$ (Termination Ia: Mix \& Ruddiman, 1985; Bard et al., 1987). Thereafter, the curve levels out until about $10700 \mathrm{BP}$, followed by a second trend of depletion until about $7000 \mathrm{BP}$. The actual measurements show that $60 \%$ of this second trend of depletion took place between about 9800 and 9000 BP (Termination Ib: Duplessy et al., 1981; Mix \& Ruddiman, 1985; Broecker et al., 1988a). After $7000 \mathrm{BP}$, the smoothed record shows a very gradual trend of minor enrichment. The similarity between the ages of the major deglaciation steps recorded in the $\delta^{18} \mathrm{O}$ record of IN68-9, and those of Terminations Ia and Ib in the standard records (Duplessy et al., 1981; Mix \& Ruddiman, 1985; Bard et al., 1987; Broecker et al., 1988a), corroborates the age-model for IN68-9 discussed above.

Rossignol-Strick et al. (1992) also constructed a $\delta^{18} \mathrm{O}$ record for the southern Adriatic, based on $G$. ruber from core KET8216, along with a detailed pollen record. Compared to our $\delta^{18} \mathrm{O}_{\text {bulloides }}$ record, their $\delta^{18} \mathrm{O}_{\text {ruber }}$ record is similarly indiscriminate concerning the Younger Dryas, although the authors argued that this period is distinctly visible in their (marine) pollen record, as is usually the case in (continental) 
age (yrs BP)

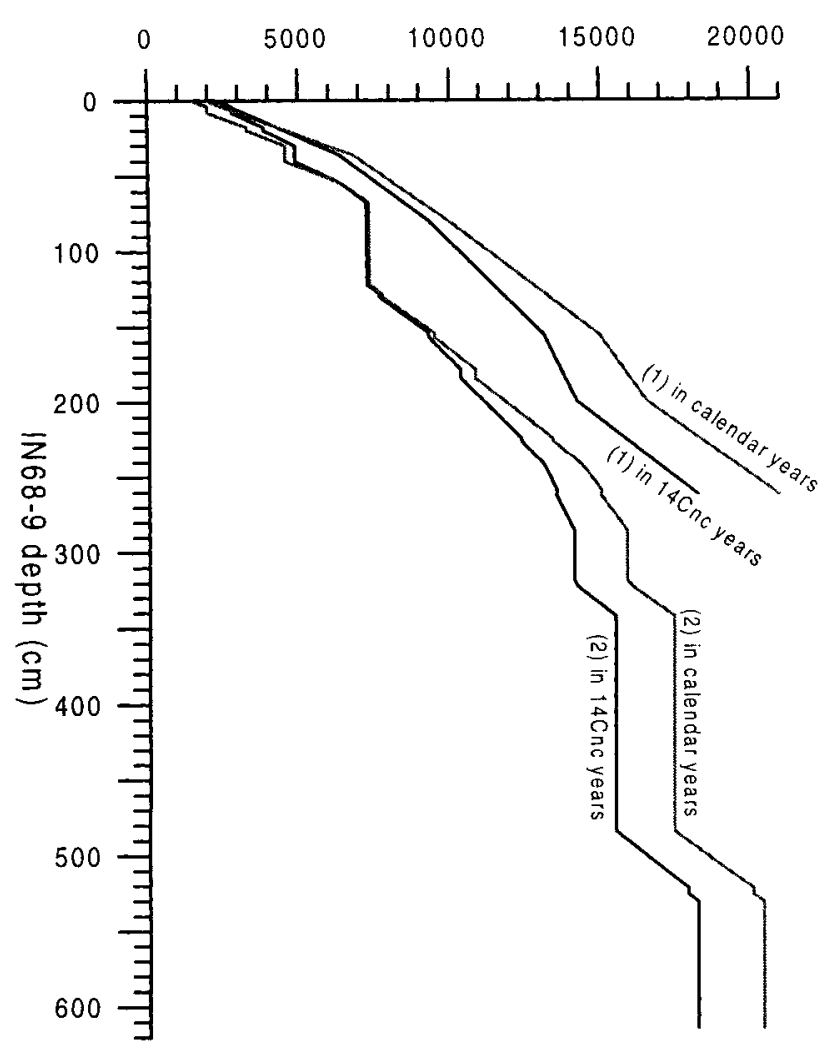

Fig. 2. Age versus depth plots for core IN68-9. (1) Turbidites and ashlayers included, assuming quasi-instantaneous deposition for those intervals (cf. Jorissen et al., 1993). (2) Excluding the turbidites and ash-layers. Solid lines are plotted versus uncorrected ${ }^{14} \mathrm{C}$ ages, grey lines versus calendar years (see conversion of ages in Table 2).

pollen sequences from circum-Mediterranean countries (e.g. Guiot, 1987; Magaritz \& Goodfriend, 1987; Pons et al., 1987; Rognon, 1987; Lowe, 1992). Our rough planktonic foraminiferal reconstruction of sea surface temperature describes a Younger Dryas-time return of colder conditions as well (see below; Fig 3). As yet, there is no ready explanation for this discrepancy between the distinct Younger Dryas expression in pollen and foraminiferal records, and its poor expression in the Adriatic $\delta^{18} \mathrm{O}_{\text {bulloides }}$ and $\delta^{18} \mathrm{O}_{\text {ruber }}$ records.

\section{FORAMINIFERA}

Planktic foraminifera

Individual species: records and interpretation. Planktic foraminifera (150-595 mm fraction; cf. Jorissen et al., 1993) are present throughout core IN68-9, except within the turbidites. In the upper $310 \mathrm{~cm}$, several large changes occur in the faunal composition (Fig. 3). A minimum of 200 specimens was counted for every sample. The relevant habitat characteristics for the species involved are summarized in Table 3, with references for further information.

Although Neogloboquadrina pachyderma (dextral) dominates the pre-12700 BP interval, Globorotalia scitula - a cool to cold water species that occurs to great depth - also is abundant. Turborotalita quinqueloba, a species that thrives in cool surface

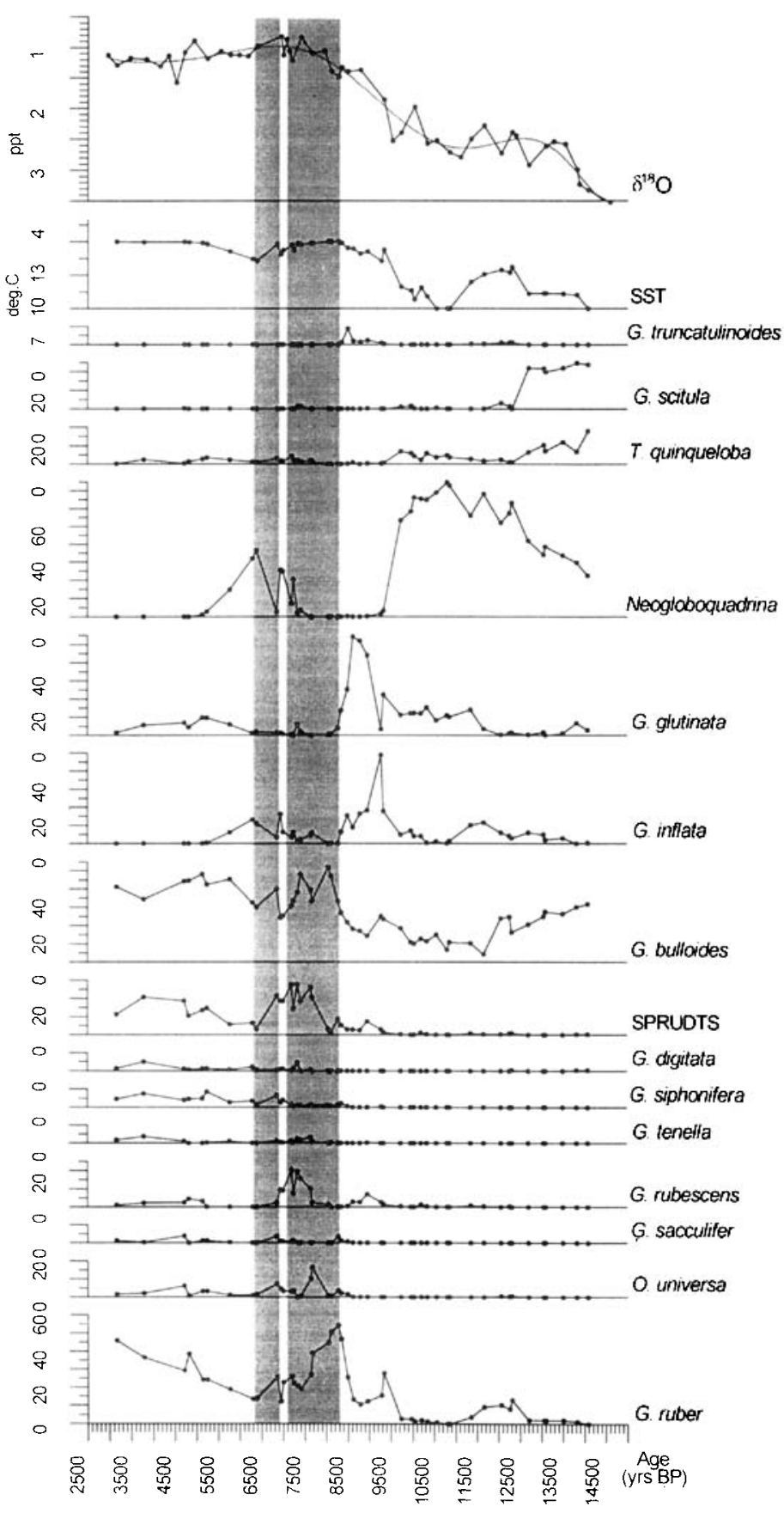

Fig. 3. Percentages of planktic foraminiferal species versus age in core IN68-9 for the past 14500 years. Shaded intervals represent the two $S_{1}$ subunits. The shaded curve in the $\delta^{18} \mathrm{O}$ record is a polynomial smoothing, to show the general trends. SPRUDTS is a faunal cluster explained in the section Individual species: records and interpretation and Table 3; the main species of this cluster are also displayed individually. SST is a Sea Surface Temperature proxy-record constructed and calibrated as discyssed in the section Sea surface temperature record. Note that the isotopic record is not that presented earlier by Jorissen $e t$ al. (1993), but completely new with a resolution similar to that of the faunal analyses. Rather than adding more samples to the Jorissen $e t$ al. (1993) record (which actually consisted of two combined sets of analyses already), we chose to avoid any possible calibration problem by running an entirely new set. 


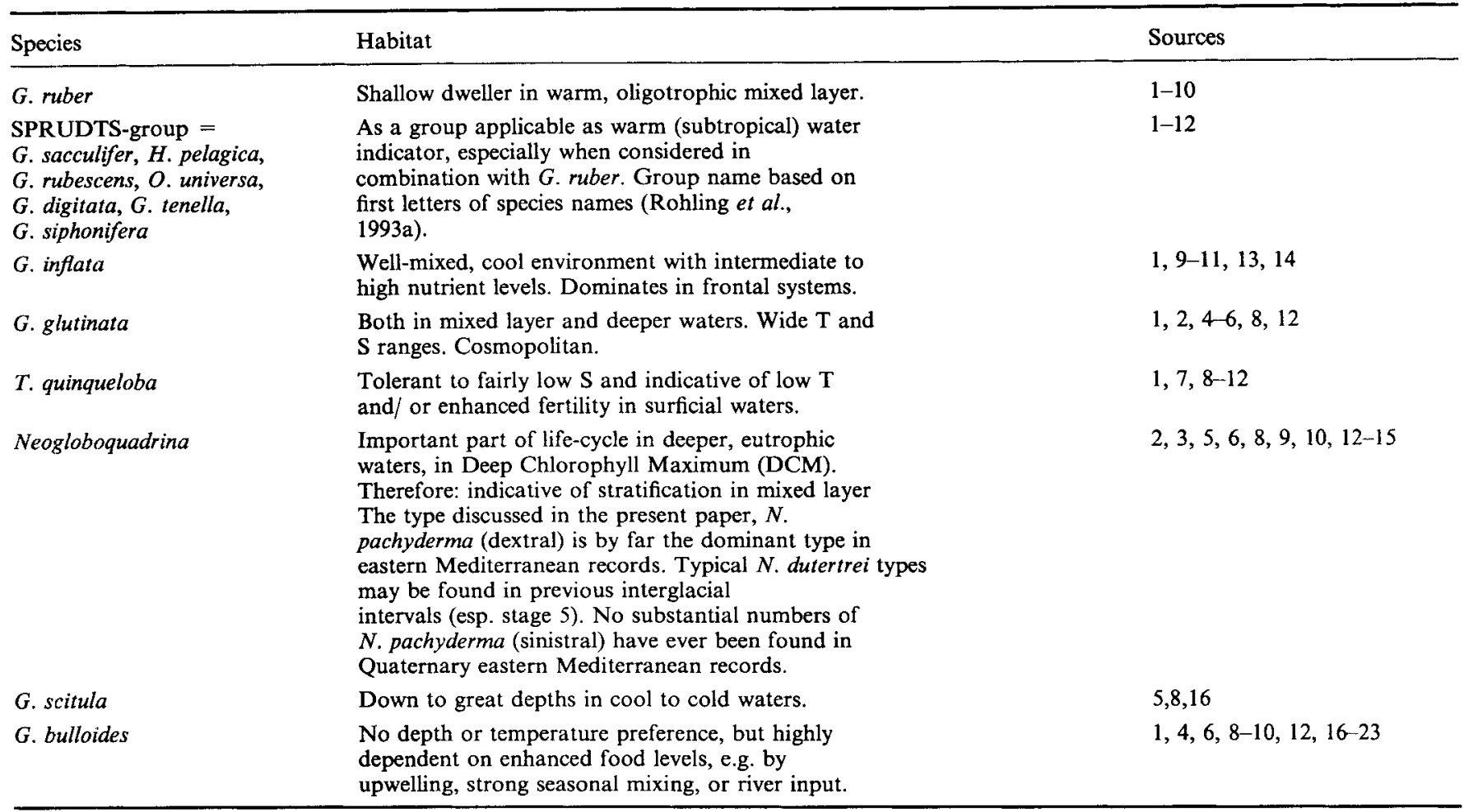

Table 3. Summary of main habitat characteristics of the planktonic foraminiferal taxa discussed in this paper (modified after review in Rohling et al., 1993a). Sources: 1, Tolderlund \& Bé (1971); 2, Fairbanks et al. (1982); 3, Hemleben \& Spindler (1983); 4, Almogi-Labin (1984); 5, Thunell \& Reynolds (1984); 6, Bé et al. (1985); 7, Vergnaud-Grazzini et al. (1986); 8, Hemleben et al. (1989); 9, Pujol \& Vergnaud-Grazzini (1989); 10, Van Leeuwen (1989); 11, Hutson (1977); 12, Reynolds \& Thunell (1989); 13, Fairbanks et al. (1980); 14, Rohling et al. (1995); 15, Fairbanks \& Wiebe (1982); 16, Bé (1969); 17, Kipp (1976); 18, Coulbourn et al. (1980); 19, Duplessy et al. (1981); 20, Thiede (1983); 21, Zhang (1985); 22, Overpeck et al. (1989); 23, Barmawidjaja et al. (1989)

waters, is common in the glacial interval as well, but, unlike $G$. scitula, it continues until about 9600 BP. Globigerinoides ruber, a warm oligotrophic mixed-layer dweller, is common after $12700 \mathrm{BP}$, although it displays a brief decrease between 11000 and 9600 BP. After 9600 BP, a marked increase occurs in the SPRUDTS-group (Globigerinoides sacculifer, Hastigerina pelagica, Globoturborotalita rubescens, Orbulina universa, Globigerinella digitata, Globoturborotalita tenella, and Globigerinella siphonifera). These individually low frequency species are grouped because of their tendency to do so in cluster analyses (Rohling et al., 1993a) and form a useful warm, subtropical water indicator, especially when considered in combination with G. ruber (Table 3 ). Note that abundances are probably not directly controlled by temperature, but rather by the degree of development of a persistent seasonal thermocline, separating a warm, oligotrophic mixed layer (habitat of 'warm' species) from cooler and more eutrophic waters below.

The faunal changes in the Adriatic Sea described above suggest ending of truly glacial conditions around $12700 \mathrm{BP}$, a poorly developed return to cooler conditions between 11000 and $9600 \mathrm{BP}$ (corresponding to the Younger Dryas), and a final ending of the glacial period around $9600 \mathrm{BP}$.

Around 9600 BP, Globorotalia inflata shows a sudden increase in dominance following a total decline of Neogloboquadrina pachyderma (d). Around $9000 \mathrm{BP}$, the high abundance of $G$. inflata is rapidly followed by high abundance of Globigerinita glutinata.

Since Neogloboquadrina pachyderma (d) thrives in eutrophic waters, and is mostly found in association with a deep chlorophyll maximum at the base of the euphotic layer fueled by upward mixing of nutrients from deeper waters (Table 3), its high abundances strongly suggest (seasonally ?) stratified conditions within the euphotic layer. $G$. inflata proliferates in well-mixed, cool environments with relatively high nutrient levels and shows peak abundances associated with strong vertical mixing and distinct frontal systems (Table 3). Hence, the abrupt decline of Neogloboquadrina pachyderma (d) in favour of $G$. inflata probably reflects disappearance of a more stably stratified habitat, and increased dominance of strong vertical mixing and/or frontal systems in relatively eutrophic waters. The subsequent change to $G$. glutinata dominance is hard to understand because of its cosmopolitan character (Table 3). Tentatively, we propose that it reflects the next phase in the decline of nutrient availability, to a system with only occasional input of nutrients from deeper waters. According to this interpretation, Neogloboquadrina pachyderma (d), G. inflata, and $G$. glutinata should have an increasing reproductionpotential, respectively. The inferred highest reproductionpotential of $G$. glutinata would enable it to numerically overwhelm the other species in response to very short-lived 
eutrophication events, which might also (partly) explain its observed cosmopolitan character. This proposal needs to be substantiated by further research on the modern characteristics of the species involved.

Globigerina bulloides is abundant throughout the record, but shows a maximum in the sapropel. In the interruption between the two sapropelic subunits, $G$. bulloides abundances drop to a temporary low. Although the percentages of $G$. bulloides above $S_{1}$ show a brief low, they subsequently return to values that are rather similar to those within $S_{1}$.

$G$. bulloides is an opportunistic species thriving in any eutrophic setting (Table 3). Plankton tows showed maximum abundance of $G$. bulloides in winter in the Tyrrhenian Sea (Vergnaud-Grazzini et al., 1986) and in late spring in other western Mediterranean basins (Vergnaud-Grazzini, 1995 pers comm.; Cifelli, 1974). Its peak abundance in especially the lower $S_{1}$ subunit suggests that sapropel formation coincided with surface water eutrophication. Previously, it has been suggested that part of this eutrophication may be ascribed to increased (Po) river discharge (Rohling et al., 1993a).

Sea surface temperature record. To estimate sea surface temperature (SST) variations, cumulative frequencies of the warm water indicators $G$. ruber and the SPRUDTS-group are calculated versus the cooler/cold water species $T$. quinqueloba, $G$. scitula, G. inflata, and Neogloboquadrina pachyderma (d). A priori grouping is easily performed and gives results comparable to those from more elaborate statistical methods (cf. Cita et al., 1977; Thunell et al., 1977; Rohling \& Gieskes, 1989; Rohling et al., 1993a). Note that our record, as all other fauna-based SST records, will be biased to some extent due to the additional dependance on nutrient availability of especially the species on the 'cool' side (e.g. Neogloboquadrina pachyderma (d) and $G$. inflata). In spite of the enhanced detail, the down-core pattern of our a priori grouping strongly resembles that derived previously using Principal Components Analysis, providing an essentially semi-quantitative indicator of 'cooling' and 'warming' trends (Rohling et al., 1993a). For a better understanding of the order of magnitude of the SST-changes involved, however, we now calibrate the percentage-variations in the a priori grouping to changes in ${ }^{\circ} \mathrm{C}$ as follows:

(1) Fossil evidence suggests that last glacial maximum (LGM) winter SST in the Adriatic was about $6^{\circ} \mathrm{C}$ lower than today $\left(1-3^{\circ} \mathrm{C}\right.$ less difference in summer) (Bigg, 1994), which is supported by a recent $\mathrm{U}^{\mathbf{k}}{ }_{37}$ based SST record suggesting about $8^{\circ} \mathrm{C}$ change in the Alboran Sea (western Mediterranean) (Cacho et al., 1994), and foraminiferal transfer function results suggesting about $5^{\circ} \mathrm{C}$ change in the Aegean Sea (Thunell, 1979). (2) Modern winter SST in the Adriatic Sea is about $13^{\circ} \mathrm{C}$ (Levitus, 1982), so that the range of about $100 \%$ change in our percentage-plot for SST should correspond to a temperaturerange between about 7 and $13^{\circ} \mathrm{C}$ (winter SST is considered since it is important for deep convection in the Adriatic). (3) Next, the rate of change in the percentage-plot needs to be calibrated to the rate of change in ${ }^{\circ} \mathrm{C}$. It is unrealistic to use a simple linear relation, since it would imply a $1: 4$ ratio for the relative proportions of the 14-12 and 10-8 kyr BP winter SST increases, whereas vegetation-based records of winter temperature in southern France (Guiot, 1987) and the $\mathrm{U}^{\mathrm{k}} 37$ based SST record for the Alboran Sea (Cacho et al., 1994) suggest a ratio of about

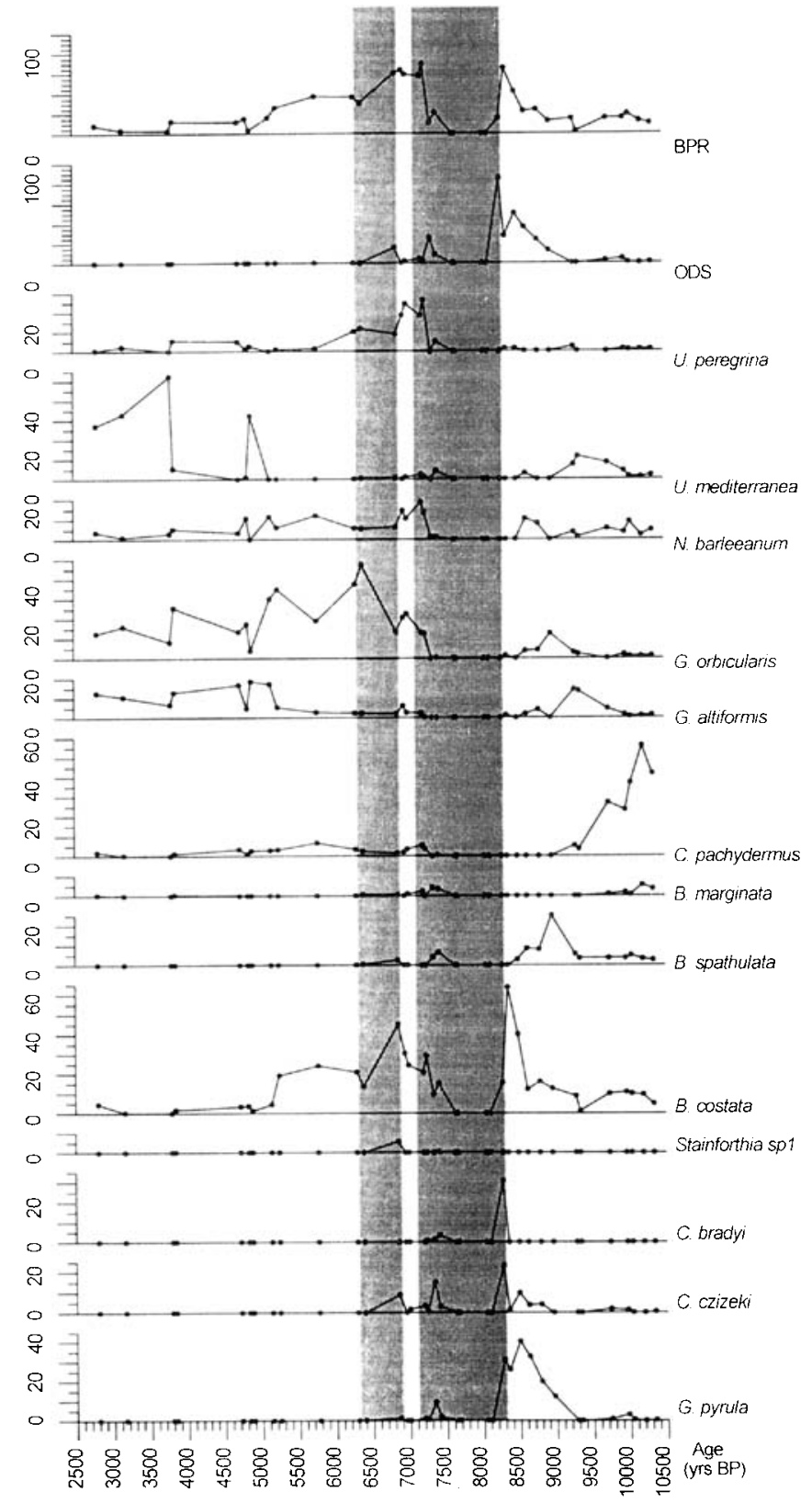

Fig. 4. Percentages of benthic foraminiferal species versus age in core IN68-9 for the past 10500 years. ODS is Oxygen Deficiency Stress group explained in the section Summary of benthic productivity and oxygen deficiency stress records. BPR is Benthic Productivity group explained in this section.

$1: 2$. We find such an approximate $1: 2$ ratio when calibrating our percentage-record to ${ }^{\circ} \mathrm{C}$ using a logarithmic relationship. (4) The resultant SST-proxy record is plotted versus age along with the other results (Figs $3 \& 5$ ).

\section{Benthic foraminifera}

Individual species: records and interpretation. The discussion of benthic foraminifera concentrates on the changes directly associated with, and for some distance below and above $S_{1}$. Hence, the benthic record shown extends from about $200 \mathrm{~cm}$ (11000 BP) to the very top of the core (Fig. 4). Benthic 


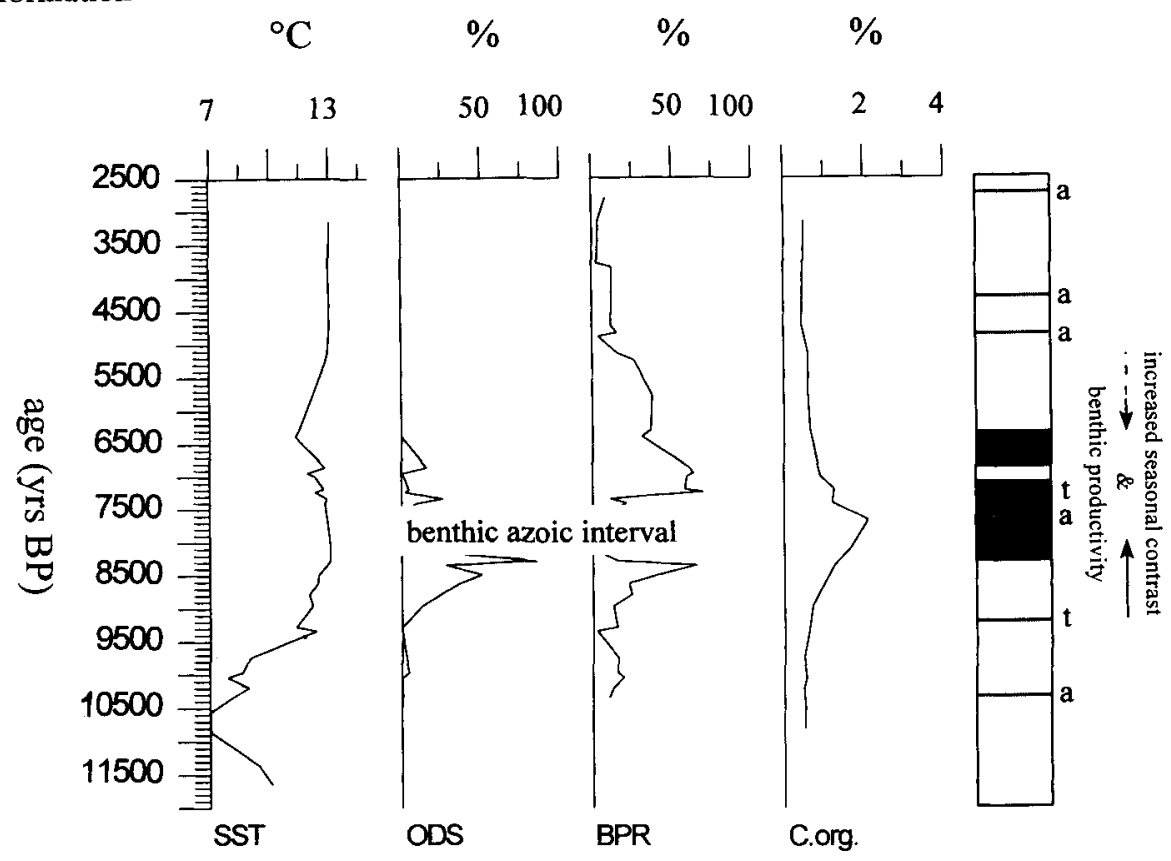

Fig. 5. Summarizing diagram of Sea Surface Temperature (SST), sea floor Oxygen Deficiency Stress (ODS), Benthic Productivity (BPR), Organic Carbon content $\left(\mathrm{C}_{\mathrm{org}}\right.$ in \%), versus age (yrs BP) in core IN68-9. In the lithological column, both $\mathrm{S}_{1}$ subunits are indicated in black, and the chronostratigraphic positions of ash layers (a) and turbidites ( $t$ ) are indicated with a shaded band.

foraminifera (150-595 $\mu \mathrm{m}$ fraction; cf. Jorissen et al., 1993) are present up to the very base of $\mathrm{S}_{1}(8300 \mathrm{BP})$. Thereafter, they are absent until $7200 \mathrm{BP}$, with the exception of the interval between 7400 and $7240 \mathrm{BP}$, just below the turbidite within the lower $\mathrm{S}_{1}$ subunit. After the lower subunit, benthic foraminifera are present throughout. At least 200 specimens were counted for every sample.

Around $9600 \mathrm{BP}$, a rather diverse fauna is found with dominant Gyroidina altiformis and Uvigerina mediterranea. This fauna is very similar to that after $5200 \mathrm{BP}$, which characterizes the relatively oligotrophic conditions of the modern Mediterranean. At about $9300 \mathrm{BP}, G$. altiformis and U. mediterranea largely disappear, while Gyroidina orbicularis and Bolivina spathulata increase in frequency, as does, somewhat later, Bulimina costata. After $8600 \mathrm{BP}$, faunal diversity becomes very low and progressively more dominated by Nonion barleeanum, Globobulimina pyrula, Chilostomella czizeki and Cassidulinoides bradyi, while $B$. costata shows a change in morphology from rather short (inflata) morphotypes with discontinuous costae to elongated (costata) types with continuous costae along the entire test.

The described faunal succession coincides with a significant increase in the organic carbon content after about $9500-9000 \mathrm{BP}$ (Fig. 5), and culminates in complete absence of benthic fauna and preservation of laminae after $8300 \mathrm{BP}$ (base $\mathrm{S}_{1}$ ), indicating persistent anoxia (Josefson \& Widbom, 1988; Bernhard \& Reimers, 1991). Combined, these patterns lead us to suggest that the faunal succession resulted from increasing fertility and decreasing oxygenation of the benthic environment. In this scenario, (1) G. orbicularis and B. spathulata would reflect the first stage of ecosystem enrichment; (2) B. costata and $N$. barleeanum would become dominant through increasing lowoxygen stress while benthic fauna can still profit from high food

\begin{tabular}{|c|c|}
\hline Taxon & Sources \\
\hline Bulimina costata & 1,2 \\
\hline Uvigerina peregrina & $3,4,5$ \\
\hline Nonion barleeanum & $1,6,7,8$ \\
\hline Globobulimina/Chilostomella & $2,8,9,10$ \\
\hline Stainforthia & 11 \\
\hline
\end{tabular}

Table 4. Benthic foraminiferal taxa proposed as indicators of ecosystem enrichment and/or oxygen depletion. The cited sources sometimes described the taxa under different names. Sources: 1, Jorissen (1987); 2 , Sen Gupta \& Machain Castillo (1993); 3, Lutze \& Coulbourn (1984); 4, Lutze (1986); 5, Altenbach \& Sarnthein (1989); 6, Mackensen et al. (1985); 7, Caralp (1989); 8, Loubere (1994); 9, Miller \& Lohmann (1982); 10, Bernhard \& Reimers (1991); 11, Alve (1990).

availability; and (3) G. pyrula, C. czizeki and C. bradyi would reflect very strong dysoxia, possibly even intermittent anoxia. These inferences based on core IN68-9 are supported by previous studies characterizing most of the involved species as indicative of ecosystem enrichment and oxygen depletion (Table 4). Specifically relevant to our proposed scenario for the observed benthic faunal succession is the common dominance of Bulimina costata, Globobulimina, Chilostomella, and Stainforthia in oxygen minimum zones around the world (Sen Gupta \& Machain-Castillo, 1993). Moreover, under well-oxygenated conditions, G. pyrula, C. czizeki and C. bradyi occupy deep infaunal habitats near the redox-front, tolerating strongly dysoxic conditions, whereas $N$. barleeanum occupies a shallower position, suggesting less tolerance to dysoxia (e.g. Corliss, 1985; Corliss \& Emerson, 1990; Jorissen et al., 1995). Nolet \& Corliss (1990) also found dominance of Globobulimina and Chilostomella directly at the base or within a number of late Quaternary 
sapropels, which they ascribe to strong low-oxygen tolerance of these taxa. As do other (potentially) infaunal species in the recent Adriatic (Barmawidjaja et al., 1992), these taxa likely follow taxon-specific critical oxygen levels that migrate towards the sediment-water interface when oxygenation deteriorates (e.g. Mackensen \& Douglas, 1989), ultimately causing species with the highest tolerance of dysoxia/intermittent anoxia to dominate the fauna, persisting at the sediment surface.

After the sterile base-interval of $S_{1}$, the first return of benthic foraminifera is found at 7400 to $7300 \mathrm{BP}$, just below the turbidite. The fauna is very diverse in that interval, containing substantial numbers of Cassidulina carinata, Trifarina angulosa, and Bulimina marginata. These species, virtually absent in the other samples, have a lower depth limit of $800 \mathrm{~m}$ in the presentday Adriatic Sea (Jorissen, 1988), so that the $7400-7240$ BP fauna seems to reflect downslope transport into a still anoxic environment. The high percentages of $C$. czizeki and $G$. pyrula suggest admixture of dysoxic lower slope $(500-800 \mathrm{~m})$ faunas with better oxygenated upper slope $(200-500 \mathrm{~m})$ faunas.

Immediately above the turbidite of $7230 \mathrm{BP}$, the benthic fauna in the lower $S_{1}$ subunit is dominated by $B$. costata, Uvigerina peregrina and $N$. barleeanum. The interruption of $\mathrm{S}_{1}$ shows an increase of $G$. orbicularis, and total disappearance of $G$. pyrula, C. czizeki, C. bradyi. Interpreted in terms of the above explanation for benthic change prior to $S_{1}$, the fauna after 7200 BP reflects slight reoxygenation of the bottom waters, in a still eutrophic benthic environment. The changes associated with the $S_{1}$ interruption (7100-6900 BP) suggest substantially improved bottom water oxygenation, while fertility in the benthic ecosystem decreased to levels comparable to those reflected in the last 500 years prior to the onset of sapropel formation.

The onset of the second $S_{1}$ subunit (6900 BP) corresponds with a return of $C$. czizeki, and a maximum of $B$. costata (elongated costata morphotypes), suggesting a return to distinct dysoxia after the reoxygenation represented by the $S_{1}$ interruption. $G$. orbicularis and inflata morphotypes of $B$. costata (encountered also below $S_{1}$ ) dominate between 6900 and $6340 \mathrm{BP}$ (second $\mathrm{S}_{1}$ subunit), continuing until $5200 \mathrm{BP}$. The ensuing frequency drop around $5200 \mathrm{BP}$ suggests that oxygenation and productivity became comparable to the present relatively oligotrophic situation. This date differs completely from that of Fontugne et al. (1989), who argued on the basis of sedimentological evidence that, since the formation of $S_{1}$, fully oxygenated conditions would only have returned around 1650 BP.

Summary of benthic productivity and oxygen deficiency stress records. To summarize the benthic faunal changes, we use the successions observed in IN68-9 to propose a clustering of species that, individually, were previously proposed to indicate ecosystem enrichment and/or oxygen depletion (Table 4). The first group consists of Bulimina costata, Uvigerina peregrina and Nonion barleeanum, characterizing a relatively advanced stage of ecosystem enrichment, where only species with a certain tolerance for low oxygen conditions can profit from the abundance of food ('Benthic Productivity' (BPR) group; Figs 4 \& 5). The second group consists of Globobulimina pyrula, Chilostomella czizeki, Cassidulinoides bradyi and Stainforthia sp., characterizing the ultimate stage before totally azoic conditions, tolerating severe low-oxygen stress ("oxygen defi- ciency stress' (ODS) group; Figs 4 \& 5). As yet, it is impossible to fully quantify the ODS and BPR proxies. Concerning the ODS-curve, however, we suggest that the taxa only becc ne present in substantial numbers (ODS score $>10 \%$ ) when bottom water oxygen concentrations become lower than 1.0 ml $1^{-1}$ (e.g., Sen-Gupta \& Machain-Castillo, 1993), while dominance (ODS score $>50 \%$ ) likely reflects virtually anoxic conditions.

The increasing BPR values between 9300 and $8500 \mathrm{BP}$ are followed by an abrupt drop immediately below the sapropel. This sudden decrease likely is an artifact, resulting from an overriding effect of severe low-oxygen stress (ODS peak). Even though the species combined in the BPR record must be fairly tolerant to low oxygen conditions, the progressively increasing oxygen deficiency presumably passed their tolerance limit around $8500 \mathrm{BP}$, so that only species tolerant of extreme lowoxygen conditions remained. This interpretation is supported by the azoic conditions (persistent anoxia) found only 200 years later (onset of $S_{1} ; 8300 \mathrm{BP}$ ).

\section{DISCUSSION AND CONCLUSIONS}

Relation between changes in the planktic and benthic environments This section focuses mainly on the relation between the proxyrecords of Sea Surface temperature (SST; Figs $3 \& 5$ ), Benthic Productivity (BPR; Figs 3 \& 4) and sea floor Oxygen Deficiency Stress (ODS; Figs $4 \& 5$ ). These records represent changes in long-term average conditions in the basin, even when words like 'abrupt' and 'rapid' are used, since the average sample resolution, relatively high as it may be, is not sufficient to address changes on time-scales smaller than about a century. The winter SST record (Figs $3 \&$ 5) suggests glacial values around $7^{\circ} \mathrm{C}$ in the southern Adriatic until a first substantial warming around $12700 \mathrm{BP}$, followed by a return to near-glacial winter SST conditions between 11000 and 10000 BP (Younger Dryas). Thereafter, a second major warming takes place until about $9500 \mathrm{BP}$, followed by a more gradual increase culminating between 8300 and $8000 \mathrm{BP}$ with near-modern temperatures $\left(13^{\circ} \mathrm{C}\right)$. The suggestion that maximum temperatures were reached around $8000 \mathrm{BP}$ is consistent with the vegetation-based palaeotemperature reonstructions for southern France (Guiot, 1987).

The high SST conditions reached around $9300 \mathrm{BP}$ suggest prevalence of a season with a relatively warm and oligotrophic mixed layer in the basin. In addition, the abundance of $G$. inflata in this interval suggests a well developed rather eutrophic, wellmixed season, while the high abundances of $G$. glutinata may also be related to a process of eutrophication (section Individual species, records and interpretation). Moreover, although still rather low, $G$. bulloides abundances start to increase after $9300 \mathrm{BP}$, suggesting increasingly favourable (eutrophic) conditions, possibly in the form of seasonal blooms. The planktic record, therefore, suggests enhanced seasonal contrasts in temperature and productivity after about $9300 \mathrm{BP}$, so that the organic flux to the sea floor (export production) must have become increasingly seasonal. Even without a change in the total annual export production, a change from a rather constant flux to a pulsed, seasonal flux would influence benthic life and increase the potential for organic matter burial in the sediment (Berger \& Wefer, 1990). Hence, the increases in the $\mathrm{C}_{\text {org }}$ content 
and the BPR record, indicating enrichment of the benthic environment, support the inferred enhanced seasonal contrasts after $9300 \mathrm{BP}$ (Fig. 5). Additional support comes from the general decrease in 'annual stability' around the Pleistocene/ Holocene boundary inferred from planktic foraminiferal faunas in a wider eastern Mediterranean context (Rohling et al., 1993a).

Around $8500 \mathrm{BP}$, the final increase of winter SST towards the maximum values of $8300-8000 \mathrm{BP}$ coincides with an increase of low-oxygen stress in the benthic community (ODS; Figs 4 \& 5), which also culminates around $8300 \mathrm{BP}$ - the onset of $S_{1}$ - in complete and persistent anoxia causing azoic conditions at the sea floor until about $7200 \mathrm{BP}$. During deposition of sapropel $S_{1}$ a gradual cooling is suggested, with some minor lows associated with the 7100-6900 BP interruption of $S_{1}$. The benthic fauna reflects some improvement of the oxygenation in a still eutrophic environment around $7200 \mathrm{BP}$, and substantially increased oxygenation between 7100 and 6900 BP. Slight warming at the base of the second sapropelic subunit (6900 BP) coincides with the return of very poorly oxygenated conditions at the sea floor. Continued gradual cooling towards the top of $S_{1}$ is accompanied by a change in the benthic fauna reflecting progressive decrease of the stress from oxygen deficiency. Finally, winter SST rises from 6340 to $4500 \mathrm{BP}$, when modern conditions were established, while around $5200 \mathrm{BP}$, benthic productivity and oxygenation arrive at present-day levels.

\section{Ventilation and/or productivity}

The BPR record suggests (well) eutrophicated conditions starting to build up about $9300 \mathrm{BP}$ (1000 years before the onset of $S_{1}$ ), and reaching a likely maximum between 8300 and $7400 \mathrm{BP}$ (considering the high values bordering the azoic interval, it seems likely that that highly/highest eutrophicated conditions prevailed during deposition of that interval). Then, a rapid decline is suggested between about $6900 \mathrm{BP}$ and $5200 \mathrm{BP}$, followed by relatively stable oligotrophic conditions. The generally enhanced seasonal contrasts in productivity inferred since about $9300 \mathrm{BP}$ (with a possible end reached around about $5500 \mathrm{BP}$ ) also suggests increased organic flux to the sea floor. This coincidence of increased (seasonality of) productivity with sapropel formation would seem to support a recent conclusion that productivity forms the primary control on enrichment of organic carbon in sediments, which was based on recent sapropel formation in the Black Sea (Pedersen \& Calvert, 1990; see review in Rohling, 1994).

However, in IN68-9, neither the record of benthic productivity, nor that of the main planktic productivity markers $G$. bulloides, Neogloboquadrina pachyderma (d), and $G$. inflata, show patterns suggestive of a causal link between short-term productivity variations and the depositional sequence of two $S_{1}$ subunits interrupted by a lighter-coloured homogeneous interval, apart from the overall correspondence of the sapropel to an interval of enhanced productivity. On the contrary, the ODS and SST records do suggest such a direct link with the depositional sequence. Enhanced SST values at the base of both $S_{1}$ subunits likely caused lowering of surface water densities, helping to install stable stratification and consequently poor or blocked deep water ventilation in the Adriatic Sea. Subsequent temperature decrease during the deposition of either sapropelic interval would have favoured some improvement of deep water ventilation, allowing benthic forms with sufficient low-oxygen tolerance to repopulate, while the culminated cooling at the end of sapropel deposition caused re-installment of good deep water ventilation and proper sea floor oxygenation.

Summarizing, the data from Adriatic core IN68-9 suggest that within a relatively eutrophic setting-caused by increased seasonal contrasts (and perhaps partly enhanced by nutrientinput via river discharge) - the onset, interruption, and final ending of $S_{1}$ deposition in the Adriatic Sea were triggered by changes in ventilation of the basin. The coincidence of SST variations with these changes in ventilation suggests a causal relationship. Although the SST changes are of a relatively small magnitude $\left(<2^{\circ} \mathrm{C}\right)$, and granted that they may not be very accurately estimated with our simple SST calibration, they still seem significant in terms of the sensitivity of Adriatic Sea ventilation to changes in its density-structure, since even relative temperature increases of the order of only $0.7^{\circ} \mathrm{C}$ might suffice to upset the basin's vertical circulation, causing onset of sapropel formation (Mangini \& Schlosser, 1986). Moreover, the density variations resulting from the inferred temperature changes should be viewed in combination with the underlying influence of 1) a strong salinity decrease in the eastern Mediterranean associated with the deglaciation (Thunell et al., 1987; Thunell \& Williams, 1989; Rohling, 1994); (2) increased humidity in the eastern Mediterranean area coinciding with the deposition of $S_{1}$ (see review in Rohling \& Hilgen, 1991). Our conclusions are similar to those based on benthic foraminiferal evidence in $S_{5}$, which identified anoxia resulting from reduced ventilation of deep waters as the critical factor in its deposition, although a surface productivity increase may have occurred immediately preceeding and during the deposition of $\mathrm{S}_{\mathrm{S}}$ (Nolet \& Corliss, 1990).

\section{Age of the original top of $S_{1}$}

Although the benthic fauna records relatively eutrophic conditions at the sea floor until $5200 \mathrm{BP}$, it also indicates a return to well oxygenated conditions (also reflected by the disappearance of lamination), i.e. ending of sapropel formation, around 6340 BP in the Adriatic Sea. This contrasts with the conclusion of Higgs et al. (1994) that sapropel formation in the open eastern Mediterranean ended as late as $5000 \mathrm{BP}$, while the present visible top of the sapropel would (1) represent a geochemical front caused by downward oxidation after the re-installment of oxygenated bottom water conditions and, therefore, (2) appear older than the original top. Similar inferences were made earlier, but, as did Higgs et al. (1994), always using cores with sedimentation rates as low as 2 to $4 \mathrm{~cm} \mathrm{kyr}^{-1}$ (De Lange et al., 1989; Lander-Rasmussen, 1991; Rohling et al., 1993a; Pruysers et al., 1991, 1993). The sedimentation rate in the $S_{1}$ interval of core IN68-9 is $\sim 15 \mathrm{~cm} \mathrm{kyr}^{-1}$, so that post-depositional reoxidation would not likely be of much importance. This expectation is confirmed by the observed match between the faunal and lithological boundaries of $S_{1}$. The $6340 \mathrm{BP}$ age for the very top of $S_{1}$ in IN68-9 suggests that it would be the lower, rather than the upper, $\mathrm{Mn}$ peak in the records of Higgs et al. (1994) that approximately matches the original top of $S_{1}$. This supports the conclusion of a study similar to that of Higgs et al. 
(1994), in which Pruysers et al. (1993; their core 9G1, SE of Crete) matched the original sapropel-top with the lower $\mathrm{Mn}$ peak, explaining the upper peak in terms of non-steady state formation of double peaks in response to increased organic carbon accumulation between 1900 and $1350 \mathrm{BP}$, causing retreat of the oxidation front.

\section{Sapropel interruption: common or rare?}

The correspondence between changes in lithology and benthic foraminiferal fauna suggests that both the sapropel interruption, and the second sapropelic subunit in core IN68-9 are genuine, and not the result of resedimentation. Van Straaten $(1966,1972)$ arrived at the same conclusion on the basis of benthic mollusc studies that relate the sapropel interruption to a period of relatively intensified winter cooling and consequently improved deep water formation.

In the northern Aegean Sea, $S_{1}$ is interrupted in cores from sites deeper than $250 \mathrm{~m}$ (Perissoratis \& Piper, 1992). These authors dated the top of $S_{1}$ at $6400 \mathrm{BP}$, and the base at $9200 \mathrm{BP}$. By interpolation, the Aegean $S_{1}$ interruption can roughly be placed between 7000 and $6700 \mathrm{BP}$. Given the inaccuracy involved in the interpolation of the AMS ${ }^{14} \mathrm{C}$-dates, the match with the age-range of the Adriatic $S_{1}$ interruption (7100$6900 \mathrm{BP}$ ) is striking. This could indicate that the reoxygenation was not only significant in the Adriatic Sea, but that improved deep water formation and increased oxygen advection to deep waters occurred on a wider scale in the eastern Mediterranean. Since the upper depth limit of $S_{1}$ in the northern Aegean Sea was much shallower than $250 \mathrm{~m}$ (Perissoratis \& Piper, 1992), it seems unlikely that the Aegean Sea itself produced deep water, as it may do today. Instead, the Aegean $S_{1}$ interruption may be primarily related to improved deep water formation in the Adriatic Sea, which potentially caused an eastern Mediterranean wide reoxygenation event. In that case, future research on other high sedimentation-rate cores throughout the basin should show interruption of $S_{1}$.

Interruptions have not only been found in Quaternary, but also in Pliocene sapropels. High-resolution study of Upper Pliocene sapropel C2 (Singa section, S. Italy), showed an ( $\sim 900$ years) interval containing high abundances of the low-oxygen tolerant benthic foraminiferal species Bulimina marginata inbetween benthic azoic intervals (Rohling et al., 1993b). Planktic foraminiferal abundance variations and stable isotopes suggest that this interval of temporarily improved sea floor oxygenation was preceeded by surface water cooling, while the return to persistently anoxic (i.e. azoic) conditions was related to warming. The low diversity benthic fauna in the repopulated interval of $\mathrm{C} 2$ indicates continuing low-oxygen stress, whereas the higher diversity fauna in the Adriatic $S_{1}$ interruption suggests a far more advanced state of reoxygenation. In Pliocene sapropel $\mathrm{C}$, therefore, the sapropel interruption appears to be caused by a short period of reoxygenation in a relatively stable, anoxic context, whereas the Adriatic record of $S_{1}$ reflects a longterm trend of progressively improving oxygenation, interrupted by a short relapse that caused the formation of the second $S_{1}$ subunit. Although the faunal expressions are not exactly alike in the studies of $\mathrm{C} 2$ and $\mathrm{S}_{1}$, both suggest a high sensitivity of the process of sapropel formation to short periods of improved deep water formation.

\section{ACKNOWLEDGEMENTS}

We thank W. J. Zachariasse, R. C. Thunell, A. E. S. Kemp, and an anonymous reviewer for stimulating discussions and critical reviews. A.M. Borsetti kindly enabled us to work with the material of core IN68-9. This study contributes to EU MAST-3 project Climatic Variability of the Mediterranean Paleocirculation (CLIVAMP), and to UNESCO-IUGS project Climates in the Past (CLIP). It is partly funded from Southampton University grant A94/18, and British Council grant JRP235.

\section{Manuscript received June 1996 \\ Manuscript accepted January 1997}

\section{REFERENCES}

Almogi-Labin, A. 1984. Population dynamics of planktonic foraminifera and pteropoda - Gulf of Aqaba, Red Sea. Proceedings K. Ned. Akad. Wet. Ser. B. Phys. Sci., 87: 481-511.

Altenbach, A. V. \& Sarthein, M. 1989. Productivity record in benthic foraminifera. In Berger, W. H., Smetacek, V. S., \& Wefer, G. (eds.) Productivity of the Ocean: Present and Past, Wiley, Chichester, 255269.

Alve, E. 1990. Variations in estuarine foraminiferal biofacies with diminishing oxygen conditions in Drammensfjord, SE Norway. In Hemleben, C., Kaminski, M. A., Kuhnt, W. \& Scott, D. B. (Eds) Paleoecology, Biostratigraphy, Paleoceanography and Taxonomy of Agglutinated Foraminifera. Kluwer, Dordrecht, 664-694.

Bard, E. 1988. Correction of accelerator mass spectrometry ${ }^{14} \mathrm{C}$ ages measured in planktonic foraminifera: paleoceanographic implication. Paleoceanography, 3: 635-645.

Bard, E., Arnold, M., Maurice, P., Duprat, J., Moyes, J. \& Duplessy, J. C. 1987. Retreat velocity of the North Atlantic polar front during the last deglaciation determined by ${ }^{14} \mathrm{C}$ accelerator mass spectrometry. Nature, 328: 791-794.

Bard, E., Hamelin, B., Fairbanks, R.G. \& Zindler, A. 1990. Calibration of the ${ }^{14} \mathrm{C}$ timescale over the past 30,000 years using mass spectrometric U-Th ages from Barbados corals. Nature, 345: 405-409.

Barmawidjaja, D. J., Van der Borg, K., De Jong, A. F. M., Van der Kaars, W. A. \& Zachariasse, W. J. 1989. Kau Basin, Halmahera, a Late Quaternary paleoenvironmental record in a poorly ventilated basin. Proceedings of the Snellius II Symposium Jakarta, Netherlands Journal of Sea Research, 24: 591-605.

Barmawidjaja, D. M., Jorissen, F. J., Puscaric, S. \& Van der Zwaan, G. J. 1992. Microhabitat selection by benthic foraminifera in the northern Adriatic Sea. Journal of Foraminferal Research, 22: 297-317.

Bé, A. W. H. 1969. Distribution of selected groups of marine invertebrates in waters south of $35^{\circ} \mathrm{S}$ Latitude. In: Antarctic Map Folio Series, 11: 9-12.

Bé, A. W. H., Bishop, J. K. B., Sverdlove, M. S. \& Gardner, W. D. 1985. Standing stock, vertical distribution and flux of planktonic foraminifera in the Panama Basin. Marine Micropaleontology, 9: 307-333.

Berger, W. H. \& Wefer, G. 1990. Export production: seasonality and intermittency, and paleoceanographic implications. Palaeogeography, Palaeoclimatolology, Palaeoecology (Global Planetary Science section), 89: 245-254.

Bernhard, J. M. \& Reimers, C. E. 1991. Benthic foraminiferal population fluctuations related to anoxia: Santa Barbara Basin. Biogeochemistry, 15: 127-149.

Bigg, G. R. 1994. An ocean circulation model view of the glacial Mediterranean thermohaline circulation. Paleoceanography, 9: 705 722.

Blechschmidt, G, Cita, M. B., Mazzei, R. \& Salvatorini, G. 1982. Stratigraphy of the western Mediterranean and southern Calabrian ridges, eastern Mediterranean. Marine Micropaleontology, 7: 101-134.

Broecker, W. S., Andree, M., Wolfli, W., Oescher, H., Bonani, G., Kennett, J. \& Peteet, D. 1988a. The chronology of the last deglaciation: implications to the cause of the Younger Dryas event. Paleoceanography, 3: 1-19.

Broecker, W. S., Andree, M., Bonani, G., Wolfi, W., Klas, M., Mix, A. \& Oeschger, H., 1988b. Comparison between radiocarbon ages 
obtained on coexisting planktonic foraminifera. Paleoceanography, 3: 647-657.

Bottema, S. \& Van Straaten, L. M. J. U. 1966. Malacology and palynology of two cores from the Adriatic Sea floor. Marine Geology, 4: 553-564.

Cacho, I., Targarona, J., Doose, H. \& Canals, M. 1994. Paleoceanographic record of the last deglaciation in two gravity cores from the western Mediterranean Sea: land-sea correlation. Abstracts of the first workshop of the Mediterranean targeted project, 21-23 November, Barcelona, Spain: 271-277.

Caralp, M. H. 1989. Size and morphology of the benthic foraminifer Melonis barleeanum: relationships with marine organic matter. Journal of Foraminiferal Research, 19: 235-245.

Cifelli, R. 1974. Planktonic foraminifera from the Mediterranean and adjacent Atlantic waters (Cruise 49 of the Atlantis II, 1969). Journal of Foraminiferal Research, 4: 171-183.

Cita, M.B. \& Grignani, D. 1982. Nature and origin of late Neogene Mediterranean sapropels. In Schlanger, S. O. \& Cita, M. B. (eds) Nature and Origin of Cretaceous Carbon-Rich Facies. Academic Press, San Diego, 165-196.

Cita, M. B., Vergnaud-Grazzini, C., Robert, C., Chamley, H., Ciaranf, N. \& d'Onofrio, D. 1977. Paleoclimatic record of a long deep sea core from the eastern Mediterranean. Quaternary Research, 8: 205-235.

Cita, M. B., Berghi, C., Camerlenghi, A., Kastens, K. A., McCoy, F., Nosetto, A., Parisi, E., Scolari, F.\& Tomadin, L. 1984. Turbidites and megaturbidites from the Herodotus Abyssal Plain (eastern Mediterranean) unrelated to seismic events. Marine Geology, 55: 79-101.

Corliss, B. H. 1985. Microhabitats of benthic foraminifera within deepsea sediments. Nature, 314: 435-438.

Corliss, B. H. \& Emerson, S. 1990. Distribution of Rose Bengal stained deep-sea benthic foraminifera from the Nova Scotian continental margin and Gulf of Maine. Deep-Sea Research, 37: 381-400.

Coulbourn, W. T., Parker, F. L. \& Berger, W. H. 1980. Faunal and solution patterns of plaktonic foraminifera in surface sediments of the North Pacific. Marine Micropaleontology, 9: 329-399.

De Lange, G. J., Middelburg, J. J. \& Pruysers, P. A. 1989. Middle and Late Quaternary depositional cycles in the eastern Mediterranean. Sedimentology, 36: 151-158.

Duplessy, J. C., Delibrias, G., Turon, J. L., Pujol, C. \& Duprat, J. 1981 Deglacial warming of the northeastern Atlantic Ocean: correlation with the paleoclimatic evolution of the European continent, Palaeogeography, Palaeoclimatology, Palaeoecology, 35: 121-144.

Fairbanks, R. G. \& Wiebe, P. H. 1982. Foraminifera and chlorophyll maximum: Vertical distribution, seasonal succession, and paleoceanographic significance. Science, 209: 1524-1525.

Fairbanks, R. G., Wiebe, P. H. \& Bé, A. W. H. 1980. Vertical distribution and isotopic composition of living planktonic foraminifera in the western North Atlantic. Science, 207: 61-63.

Fairbanks, R. G., Sverdlove, M., Free, R., Wiebe, P. H. \& Bé, A. W. H 1982. Vertical distribution of living planktonic foraminifera from the Panama Basin. Nature, 298: 841-844.

Fontugne, M. R., Paterne, M., Calvert, S. E., Murat, A., Guichard, F. \& Arnold, M. 1989. Adriatic deep water formation during the Holcoene: implication for the reoxygenation of the deep eastern Mediterranean Sea. Paleoceanography, 4: 199-206.

Guiol, J. 1987. Late Quaternary climatic change in France estimated from multivariate pollen time series. Quaternary Research, 28: 100 118.

Hemleben, Ch. \& Spindler, M. 1983. Recent advances in research on living planktonic foraminifera. In Meulenkamp, J. E. (Ed.) Reconstruction of Marine Paleoenvironments. Utrecht Micropaleontology Bulletin, 30: 141-170.

Hemleben, Ch., Spindler, M. \& Anderson, O. R. 1989. Modern Planktonic Foraminifera. Springer, New York, 363 pp.

Higgs, N. C., Thomson, J., Wilson, T. R. S. \& Croudace, I. W. 1994. Modification and complete removal of eastern Mediterranean sapropels by postdepositional oxidation. Geology, 22: 423-426.

Hilgen, F. J. 1991. Astronomical calibration of Gauss to Matuyama sapropels in the Mediterranean and implication for the Geomagnetic Polatity Time Scale. Earth and Planetary Science Letters 104: 226-244.

Hutson, W. H. 1977. Variations in planktonic foraminiferal assemblages along north-south transects in the Indian Ocean. Marine Micro- paleontology, 2: 47-66.

Jorissen, F. J, 1987. The distribution of benthic foraminifera in the Adriatic Sea. Marine Micropaleontology, 12: 21-48.

Jorissen, F. J. 1988. Benthic foraminifera from the Adriatic Sea; principles of phenotypic variation. Utrecht Micropaleontology Bulletin, 37: $174 \mathrm{pp}$.

Jorissen, F. J., Asioli, A., Borsetti, A. M., Capotondi, L., De Visser, J. P., Hilgen, F. J., Rohling, E. J., Van der Borg, K., Vergnaud-Grazzini, C. \& Zachariasse, W. J. 1993. Late Quaternary central Mediterranean biochronology. Marine Micropaleontology, 21: 169-189.

Jorissen, F. J., De Stigter, H. C. \& Widmark, 1995. A conceptual model explaining benthic foraminiferal microhabitats. Marine Micropaleontology, 26: 3-15.

Josefson, A. B. \& Widbom, B. 1988. Differential response of benthic macrofauna and meiofauna to hypoxia in the Gullmar Fjord basin. Marine Biology, 100: 31-40.

Kipp, N. G. 1976. New transfer function for estimating past sea-surface conditions from sea-bed distribution of planktonic foraminiferal assemblages in the North Atlantic. In Cline, R. M. \& Hays, J. D. (Eds), Investigation of Late Quaternary Paleoceanography and Paleoclimatology. Memoirs of the Geological Society of America, 145: $3-41$.

Lander Rasmussen, T. 1991. Benthonic and planktonic foraminifera in relation to the Early Holocene stagnation in the Ionian Basin, central Mediterranean. Boreas, 20: 357-376.

Levitus, S. 1982. Climatological atlas of the world ocean. NOAA Professional Paper, 13: 1-173.

Loubere, P. 1994. Quantitative estimation of surface ocean productivity and bottom water oxygen concentration using benthic foraminifera. Paleoceanography, 9: 723-737.

Lowe, J. J. 1992. Late glacial and early Holocene lake sediments from the northern Apennines, Italy - pollen stratigraphy and radiocarbon dating. Boreas, 21: 193-208.

Lutze, G. F. 1986. Uvigerina species of the eastern North Atlantic. Utrecht Micropaleontology Bulletin, 35: 21-46.

Lutze, G.F. \& Coulbourn, W. T. 1984. Recent benthic foraminifera from the continental margin of northwest Africa: community structure and distribution. Marine Micropaleontology, 8: 361-401.

Mackensen, A. \& Douglas, R. 1989. Down-core distribution of live and dead deep-water benthic foraminifera in box cores from the Weddell Sea and the California borderland. Deep-Sea Research, 36: 879-900.

Mackensen. A., Sjerup, H. P. \& Jansen, E. 1985. The distribution of living benthic foraminifera on the continental slope and rise off southwest Norway. Marine Micropaleontology, 9: 275-306.

Magaritz, M. \& Goodfriend, G. A. 1987. Movement of the desert boundary in the Levant from latest Pleistocene to early Holocene. In Berger, W. H \& Labeyrie, L. D. (Eds), Abrupt Climatic Change. NATO Advanced Study Institute, Series C, Mathematical and Physical Science, 173--183.

Malanotte-Rizzoli, P. \& Hecht, A. 1988. Large-scale properties of the eastern Mediterranean: a review. Oceanologica Acta, 11: 323-335.

Mangini, A. \& Schlosser, P. 1986. The formation of eastern Mediterranean sapropels. Marine Geology, 72: 115-124.

Miller, K. G. \& Lohmann, G. P. 1982. Environmental distribution of Recent benthic foraminifera on the northeast United States continental slope. Geological Society of America Bulletin, 93: 200-206.

Mix, A. C. \& Ruddiman, W. F. 1985. Structure and timing of the last deglaciation: oxygen-isotope evidence. Quaternary Science Reviews, 4: 59-108.

Nolet, G. J. \& Corliss, B. H. 1990. Benthic foraminiferal evidence for reduced decp-water circulation during sapropel formation in the eastern Mediterranean. Marine Geology, 94: 109-130.

Overpeck, J. T, Peterson, L. C., Kipp, N., Imbrie, J. \& Rind, D. 1989. Climate change in the circum-North Atlantic region during the last deglaciation. Nature, 338: 353-357.

Pedersen, T. F. \& Calvert, S. E. 1990. Anoxia vs. productivity: what controls the formation of organic-carbon-rich sediments and sedimentary rocks? American Association of Petroleum Geologists Bulletin, 74: $454-466$.

Perissoratis, C. \& Piper, D. J. W. 1992. Age, regional variation and shallowest occurrence of $S_{1}$ sapropel in the northern Aegean Sea. Geomarine Letters, 12: 49-53. 
Pollak, M. I. 1951. The sources of deep water of the eastern Mediterranean Sea. Deep-Sea Research, 10: 128-152.

Pons, A., De Beaulieu, J.-L., Guiot, J. \& Reille, M. 1987. The Younger Dryas in southwestern Europe: an abrupt climatic change as evidenced from pollen records. In Berger, W. H. \& Labeyrie, L. D. (Eds), Abrupt Climatic Change. NATO Advanced Study Institute, Series C, Mathematical and Physical Science: 195-208.

Pruysers, P. A., De Lange, G. J. \& Middelburg, J. J. 1991. Geochemistry of eastern Mediterranean sediments: Primary sediment composition and diagenetic alterations. Marine Geology, 100: 137-154.

Pruysers, P. A., De Lange, G. J., Middelburg, J. J. \& Hydes, D. J. 1993. The diagenetic formation of metal-rich layers in sapropel-containing sediments in the eastern Mediterranean. Geochimica et Cosmochimica Acta, 57: 527-536.

Pujol, C. \& Vergnaud-Grazzini, C. 1989. Palaeoceanography of the Last Deglaciation in the Alboran Sea (Western Mediterranean). Stable isotopes and planktonic foraminiferal records. Marine Micropaleontology, 15: 153-179.

Reynolds, L. A. \& Thunell, R. C. 1989. Seasonal succession of planktonic foraminifera: results from a four-year time-series sediment trap experiment in the northeast Pacific. Journal of Foraminiferal Research, 19: 253-267.

Rognon, P. 1987. Aridification and abrupt climatic events on the Saharan northern and southern margins, $20000 \mathrm{Y}$ BP to present. In Berger, W. H. \& Labeyrie, L. D. (Eds), Abrupt Climatic Change. NATO Advanced Study Institure, Series C, Mathematical and Physical Science: 209-220.

Rohling, E. J. 1994. Review and new aspects concerning the formation of eastern Mediterranean sapropels. Marine Geology, 122: 1-28.

Rohling, E. J. \& Gieskes, W. W. C. 1989. Late Quaternary changes in Mediterranean Intermediate Water density and formation rate. Paleoceanography, 4: 531-545.

Rohling, E. J. \& Hilgen, F. J. 1991. The eastern Mediterranean climate at times of sapropel formation: a review. Geologie en Mynbouw, 70: 253-264.

Rohling, E. J., Jorissen, F. J., Vergnaud-Grazzini, C. \& Zachariasse, W. J. 1993a. Northern Levantine and Adriatic Quaternary planktic foraminifera; reconstruction of paleoenvironmental gradients. Marine Micropaleontology, 21: 191-218.

Rohling, E. J., De Stigter, H. C., Vergnaud-Grazzini, C. \& Zaalberg, R. 1993b. Temporary repopulation by low-oxygen tolerant benthic foraminifera within an Upper Pliocene sapropel: evidence for the role of oxygen depletion in the formation of sapropels. Marine Micropaleontology, 22: 207-219.

Rohling, E. J., Den Dulk, M, Pujol, C. \& Vergnaud-Grazzini, C. 1995. Abrupt hydrographic change in the Alboran Sea (western Mediterranean) around 8000 yrs BP. Deep-Sea Research I, 42: 1609-1619.

Rossignol-Strick, M. 1985. Mediterranean Quaternary sapropels, an immediate response of the African monsoon to variations in insolation. Palaeogeography, Palaeoclimatology, Palaeoecology, 49: 237-263.

Rossignol-Strick, M., Nesteroff, V., Olive, P. \& Vergnaud-Grazzini, C. 1982. After the deluge; Mediterranean stagnation and sapropel formation. Nature, 295: 105-110.

Rossignol-Strick, M., Planchais, N., Paterne, M. \& Duzer, D. 1992. Vegetation dynamics and climate during the deglaciation in the south Adriatic basin from a marine record. Quaternary Science Reviews, 11: $415-423$.

Sen Gupta, B. K. \& Machain-Castillo, M. L. 1993. Benthic foraminifera in oxygen-poor habitats. Marine Micropaleontoiogy, 20: 183-201.

Stanley, D. J. \& Maldonado, A. 1979. Levantine Sea-Nile cone lithostratigraphic evolution: quantitative analysis and correlation with paleoclimatic and eustatic oscillations in the late Quaternary. Sedimentary Geology, 23: 37-65.

Stanley, D. J., Knight, R. J., Stuckenrath, R, \& Catani, G. 1978. High sedimentation rates and variable dispersal patterns in the western Hellenic Trench. Nature, 273: 110-113.

Stuiver, M. \& Reimer, P. J. 1993. Extended ${ }^{14} \mathrm{C}$ data base and revised CALIB $3.0{ }^{14} \mathrm{C}$ age calibration program. Radiocarbon, 35: 215-230.

Stuiver, M., Braziunas, T. F., Becker, B. \& Kromer, B. 1991. Climatic, solar, oceanic, and geomagnetic influences on Late-Glacial and Holocene atmospheric ${ }^{14} \mathrm{C} /{ }^{12} \mathrm{C}$ change. Quaternary Research, 35: 124.

Thiede, J. 1983. Skeletal plankton and nekton in upwelling water masses off northwestern South America and northwest Africa. In Suess, E. \& Thiede, J. Coastal Upwelling, pt. A. Plenum, New York, 183-207.

Thunell, R. C. 1979. Eastern Mediterranean Sea during the Last Glacial Maximum; and 18000 years BP reconstruction. Quaternary Research, 11: $353-372$.

Thunell, R. C. \& Reynolds, L. A. 1984. Sedimentation of planktonic foraminifera: Seasonal changes in species flux in the Panama Basin. Micropaleontology, 30: 243-262.

Thunell, R. C. \& Williams, D. F. 1989. Glacial-Holocene salinity changes in the Mediterranean Sea: hydrographic and depositional effects. Nature, 338: $493-496$.

Thunell, R. C., Williams, D. F. \& Kennett, J. P. 1977. Late Quaternary paleoclimatology, stratigraphy and sapropel history in eastern Mediterranean deep-sea sediments. Marine Micropaleontology, 2: 371 -388.

Thunell, R. C., Williams, D. F. \& Belyea, P. R. 1984, Anoxic events in the Mediterranean Sea in relation to the evolution of Late Neogene climates. Marine Geology, 59: 105-134.

Thunell, R. C., Williams, D. F. \& Howell, M. 1987. AtlanticMediterranean water exchange during the late Neogene. Paleoceanography, 2: 661-678.

Tolderlund, D. S. \& Bé, A. W. H. 1971. Seasonal distribution of planktonic foraminifera in the western North Atlantic. Micropaleontology, 17: 297-329.

Troelstra, S. R., Ganssen, G. M., Van der Borg, K. \& De Jong, A. F. M. 1991. A late Quaternary stratigraphic framework for eastern Mediterranean sapropel $S_{1}$ based on AMS ${ }^{14} \mathrm{C}$ dates and stable oxygen isotopes. Radiocarbon, 33: 15-21.

Van Leeuwen, R. J. W. 1989. Sea-floor distribution and late Quaternary faunal patterns of planktonic and benthic foraminifera in the Angola Basin. Utrecht Micropaleontology Bulletin, 38: $288 \mathrm{pp}$.

Van Straaten, L. M. J. U. 1966. Micro-Malacological investigation of cores from the southeastern Adriatic Sea. Proc. Kon. Ned. Akad. Sci. Ser. B., 69: 429-445.

Van Straaten, L. M. J. U. 1970. Holocene and late-Pleistocene sedimentation in the Adriatic Sea. Geologische Rundschau, 60: 106131.

Van Straaten, L. M. J. U. 1972. Holocene stages of oxygen depletion in deep waters of the Adriatic Sea, in Stanley, D. J. (Ed.) The Mediterranean Sea., Dowden, Hutchingson \& Ross, Stroudsburg, 631-643.

Van Straaten, L. M. J. U. 1985. Molluscs and sedimentation in the Adriatic Sea during late-Pleistocene and Holocene times. Giornale di Geologia, Ser. 3a, 47: 181-202.

Vergnaud-Grazzini, C. 1985. Mediterranean late Cenozoic stable isotope record: Stratigraphic and paleoclimatic implications. In Stanley, D. J. $\&$ Wezel, F. C. (eds) Geological Evolution of the Mediterranean Basin. Springer, New York, 413-451

Vergnaud-Grazzini, C., Ryan, W. B. F. \& Cita, M. B. 1977. Stable isotope fractionation, climatic change and episodic stagnation in the eastern Mediterranean during the late Quaternary. Marine Micropaleontology, 2: 353-370.

Vergnaud-Grazzini, C., Glaçon, G., Pierre, C., Pujol, C. \& Urrutiaguer, M. J. 1986. Foraminiferes planctoniques de Méditerranée en fin d'été. Relations avec les structures hydrologiques. Memoria della Società Geologica Italiana, 36: 175-188.

Vismara Schilling, A. 1984. Holocene stagnation event in the eastern Mediterranean. Evidence from deep-sea benthic foraminifera in the Calabrian and western Mediterranean ridges. Benthos '83; 2nd International Symposium Benthic Foraminifera (Pau, April 1983), Pau and Bordeaux, France: 585-596.

Wüst, G. 1961. On the vertical circulation of the Mediterranean Sea. Journal of Geophysical Research, 66: 3261-3271.

Zhang, J. 1985. Living planktonic foraminifera from the Eastern Arabian Sea. Deep-Sea Research, 32: 789-798. 